\title{
DIATOMS COMMUNITY AND ECOLOGICAL STATUS IN OHRID LAKE, INFLUENCE BY VERDOVA RIVER
}

\author{
Bahiti E. ${ }^{1}$, Kupe $\mathbf{L}^{2^{*}}$ \\ ${ }^{1}$ University of "Alekander Xhuvani”, Elbasan, Albania; \\ $2^{2 *}$ Department of Agronomy Sciences, Faculty of Agriculture and Environmental, Agricultural University of Tirana, \\ Albania;
}

Corresponding author: Kupe L, *email: lirika_kupe@yahoo.com; elonabahiti@gmail.com;

Received August 2018; Accepted September 2018; Published October 2018;

DOI: https://doi.org/10.31407/ijees8430

UOI license: http://u-o-i.org/1.01/ijees/58557480

\begin{abstract}
Ohrid Lake is a tectonic lake and he has many endemic species covering the whole food-chain, from phytoplankton to fish. The biological investigation was based on a microscopic examination of diatom communities, which are the mostly common used as bio indicators of aquatic system health. The diatom community are collected on August 2011, like epiphyte in different macrophytes and in different depth from shoreline in estuaries of Vërdova river (T6: $5 \mathrm{~m}, 6.5 \mathrm{~m}, 9 \mathrm{~m}, 11 \mathrm{~m}, 12 \mathrm{~m}, 13 \mathrm{~m}, 14 \mathrm{~m}, 19 \mathrm{~m})$. In this paper in total we will present 8 samples, in which sample we have determined many diatoms species and ecological status in each sample. Several studies have clearly demonstrated that diatom community's change with increasing concentrations of both organic and inorganic load of substances, making them the preferred organism group for in situ biomonitoring methods. This study clearly showed that it was the shift in dominance of certain species, as shown by relative abundances and they reflected in water ecology in Lake Ohrid. A pennate diatom was classified as the most dominant species in eight samples; we have identified many endemic species. The trophic classes oscillated from 2.1 (meso-eutroph) to 2.6 (eutroph) and saprobic classes oscillated from 1.4 (oligosaprob) to 1.6 (Oligosaprob deri $\beta$-mesosaprob). Implementation of Waste Water Treatment Plant in Pogradeci town, will improve the ecological status in the Lake.
\end{abstract}

Keywords: Diatoms community, ecological status, Vërdova River, species. 